\title{
EFFECTS OF DIETARY PROTEIN LEVEL ON CATA- BOLIC RATES OF MYOSIN AND ACTIN IN THE RAT REVEALED BY URINARY EXCRETION OF 3-METHYLHISTIDINE
}

\author{
Naoyuki Nishizawa, ${ }^{1}$ Ryuhei FunABIKI, ${ }^{2}$ and Shin-ichi HareYAmA ${ }^{1}$ \\ ${ }^{1}$ Department of Agricultural Chemistry, Iwate University, Morioka, \\ Iwate and ${ }^{2}$ Department of Agricultural Chemistry, \\ Tokyo Noko University, Fuchu-shi, Tokyo
}

Myosin and actin contain 3-methylhistidine $(1,2)$ which is synthesized after the formation of the peptide chain and is not reutilized for the protein synthesis after it is released by the breakdown of the protein (3). Since the main part of 3-methylhistidine in urine is due to the breakdown of myosin and actin (4), we can estimate the catabolic rates of these proteins by measuring the urinary excretion of 3methylhistidine. Asatoor and Armstrong suggested the usefulness of urinary 3methylhistidine as an index of muscle protein turnover (1) and YounG et al. (5) used this method to estimate the catabolic rate of human muscle protein during starvation.

In the present investigation, we measured urinary 3-methylhistidine in the rat at various levels of dietary protein intake, since few works have been published on the catabolic rates of myofibrillar proteins related to dietary protein intake.

Male rats of the Wistar strain, weighing 200 to $260 \mathrm{~g}$ were used. During the preliminary period, rats were fed $20 \%$ casein diet. After 7 days, rats were divided into 4 groups of 6 each, and fed $10 \%, 20 \%, 40 \%$ and $60 \%$ casein diet respectively with controlled feeding of $12 \mathrm{~g}$ per day per rat for 4 weeks. Each diet contained the above mentioned percentage of casein, $5 \%$ of soybean oil, $4 \%$ of salt mixture (6), $0.85 \%$ of vitamin mixture (6), $0.15 \%$ of choline chloride and corn starch with which the diet was made up to $100 \%$.

The diet did not contain 3-methylhistidine. Urine samples were collected during the last 6 days of the test period and were hydrolyzed in $6 \mathrm{~N} \mathrm{HCl}$ for $2 \mathrm{hr}$ at $110^{\circ} \mathrm{C}$ to convert $n$-acetyl-3-methylhistidine to 3-methylhistidine (3). The highest value of 3-methylhistidine was obtained after hydrolysis for $2 \mathrm{hr}$. Analyses of 3methylhistidine in the hydrolyzates were performed on a JEOL-5AH amino acid analyzer. Chromatography was carried out on a column $(0.8 \times 26 \mathrm{~cm})$ of JEOL LC-R-2 resin. The buffer and starting column temperature were $0.38 \mathrm{~N}$ sodium

\footnotetext{
1 西沢直行, 2 舩引龍平, 1 晴山信一
} 
citrate, $\mathrm{pH} 4.26$ and $30^{\circ} \mathrm{C}$, respectively. At $150 \mathrm{~min}$ the temperature was increased to $57^{\circ} \mathrm{C}$. Under these conditions, histidine and 3-methylhistidine were completely

Table 1. Urinary 3-methylhistidine of rats fed diets containing various levels of protein.

\begin{tabular}{cc}
\hline Diet & $\begin{array}{c}\text { 3-Methylhistidine in urine } \\
(\mathrm{mg} / 100 \mathrm{~g} \text { body weight } / 24 \mathrm{hr})\end{array}$ \\
\hline $10 \%$ casein & $0.118 \pm 0.020^{1}$ \\
$20 \%$ casein & $0.117 \pm 0.025$ \\
$40 \%$ casein & $0.133 \pm 0.014^{\mathrm{a}}$ \\
$60 \%$ casein & $0.137 \pm 0.015^{\mathrm{b}}$ \\
\hline
\end{tabular}

${ }^{1}$ Mean \pm s. e. $m$. of 5 to 6 rats.

a $P<0.2$ compared to $20 \%$ casein.

b $P<0.1$ compared to $20 \%$ casein.

separated. Duplicate determinations showed the accuracy of this method to be within $2.8 \%$.

Table 1 shows that the urinary excretion of 3-methylhistidine per day per $100 \mathrm{~g}$ body weight tends to increase with increasing dietary protein level. When dietary protein level raises from 20 to $40 \%$ and 20 to $60 \%$, urinary excretion of 3-methylhistidine increases 13 and $16 \%$, respectively. But no difference is detected between 10 and $20 \%$ dietary protein level.

If the breakdown of myosin and actin obeys to first order kinetics, and this is very probable (7-10), the amount of urinary excretion of 3-methylhistidine should be proportional to the amount of myosin and actin in skeletal muscle. To cancel such an effect of different amount of muscle protein which has correletion with body weight (11), on excretion of 3-methylhistidine, the data are presented as per $100 \mathrm{~g}$ body weight. So the data (Table 1) represent the quantities proportional to fractional catabolic rates of myosin and actin rather than the catabolic rate themselves.

Taking into account an assumption, namely, that myosin and actin have the same fractional turnover rate (12) and also no change occurs on 3-methylhistidine content in myosin and actin under this experimental condition, the results presented here support the conclusion that higher protein intake tends to bring about increase in fractional catabolic rate of myosin and actin in skeletal muscle.

The same but statistically significant results (13) in rats fed diets containing ovalbumin at various levels encourage us to persist in the conclusion mentioned above, though we fail to clarify the difference among the dietary groups at highly significant levels in this experiment. The mechanism that controls these changes is beyond the scope of this experiment.

We thank Drs. T. Noguchi and V. R. Young for their helpful discussions. 


\section{REFERENCES}

1) Asatoor, A. M. and Armstrong, M. D., Biochem. Biophys. Res. Commun., 26, 168 (1967).

2) Johnson, P., Harris, C. I., and Perry, S. V., Biochem. J., 105, 361 (1967).

3) Young, V. R., Alexis, S. D., Baliga, B. S., Munro, H. N., and Muecke, W., J. Biol. Chem., 247, 3592 (1972).

4) Nishizawa, N., Funabiki, R., Shimbo, M., and Hareyama, S., Manuscript in preparation (1975).

5) Young, V. R., Harverberg, L. N., Bilmazes, C., and Munro, H. N., Metab. Clin. Exp. 22, 1429 (1973).

6) Harper, A. E., J. Nutr., 68, 405 (1959).

7) Funabiki, R. and Kandatsu, M., J. Biochem. (Tokyo), 64, 717 (1968).

8) Goldberg, A. L., J. Biol. Chem., 244, 3223 (1969).

9) Millward, D. J., Clin. Sci., 39, 577 (1970).

10) Rabinowitz, M., Amer. J. Cardiol., 31, 202 (1973).

11) Yamaguchi, M. and Kandatsu, M., Agr. Biol. Chem., 37, 579 (1973).

12) Funabiki, R. and Cassens, R. G., Nature New Biol., 236, 249 (1972).

13) Nishizawa, N., Funabiki, R., Shimbo, M., and Hareyama, S., Manuscript in preparation (1975). 